\title{
PROBLEMATIKA PUTUSAN MAHKAMAH KONSTITUSI TENTANG DERAJAT KETERWAKILAN TINGGI DALAM SENGKETA ALOKASI KURSI PEMILU
}

(Problems of Constitutional Court Verdict on High Proportional Degree In the Allocation of Election Seats Dispute)

\author{
M. Faishal Aminuddin \\ Program Studi IImu Politik, FISIP Universitas Brawijaya \\ Jalan Veteran Malang, Jawa Timur \\ Email:mfaishal@gmail.com
}

Naskah diterima: 30 Maret 2014; revisi: 11 April 2014; disetujui: 28 April 2014

\begin{abstract}
Abstrak
Demokratisasi Indonesia menghasilkan sengketa politik-pemilu dalam tensi yang tinggi. Mahkamah Konstitusi mempunyai kewenangan untuk mengadili setiap perkara gugatan sengketa pemilu dan pilkada. Sejauhmana putusan Mahkamah terkait dengan sengketa pemilu dapat dinilai? Secara umum, dari berbagai putusan yang dihasilkan, Mahkamah masih menghadapi problematika terkait dengan metode interpretasi yang menjadi hal krusial dalam menghasilkan kualitas putusan yang bisa diterima dengan baik. Artikel ini bertujuan untuk mengelaborasi metode interpretasi konstitusi dan hubungannya dengan uji konstitusi antara tradisi Kelsenian dan Madisonian. Lalu menekankan pada logika inter-konektivitas antara legislasi, metode interpretasi dan hasil putusan mahkamah. Berbagai aspek yang bisa dilihat dari sengketa pemilu, diantaranya perhitungan suara, alokasi kursi, kecurangan penyelenggaraan dan manipulasi lainnya dalam proses pemilu. Tulisan ini melakukan eksplorasi terhadap satu aspek yaitu alokasi kursi dimana akan dilakukan pengujian kritis atas putusan mahkamah tentang derajat keterwakilan tinggi. Metode yang digunakan adalah uji kadar keterwakilan tinggi dengan indeks Galagher dan Pukelsheim dari putusan Mahkamah terhadap sengketa alokasi kursi. Hasilnya, kualitas putusan tersebut tidak lebih baik dari putusan Komisi Pemilihan Umum yang mereka batalkan. Dari ulasan tersebut, perlu dilakukan perbaikan terhadap metode interpretasi Mahkamah.
\end{abstract}

Kata Kunci: Putusan Mahkamah Konstitusi, Sengketa Pemilu, Derajat Keterwakilan Tinggi

\section{Abstract}

Democratization in Indonesia yield high tension of political-election dispute. Constitutional Court has authority to judge any lawsuit on both election and local government election dispute. How good The Constitutional Court verdicts on election? Refers to yielding of any verdict, The Constitutional Court itself facing problems with the methods of interpretation and became crucial point to yield good and acceptable verdict. This article aim to elaborate method of interpretation of constitution connecting to review of constitution between Kelsenian and Madisonian's tradition. Furthermore it emphasize the logic of inter connection among legislation, method of interpretation and The Constitutional Court's verdict. Review to election disputes in the constitutional court, many aspects such as counts of vote, seat allocation, election fraud and technical manipulation in the election process happened. This paper focus on exploring the aspect of seat allocation. It will examine with critical review those issues of degree of proportionality in The Constitutional Court verdicts. The method used is the Index Gallagher and Pukelsheim to explain the degree of proportionality in the Constitutional Court's verdicts against the allocation of seats. As result, the quality of the Court's verdicts is not better than the Election Commission's verdicts that they canceled. From those evidence, The Constitutional Court's method of interpretation should be improved.

Keywords: Constitutional Court's Verdict, Election Dispute, Proportionality Degree 


\section{A. Pendahuluan}

Dari tiga kali pemilihan umum (pemilu) yang digelar setelah tahun 1998, terdapat berbagai macam hal yang bisa dilihat sebagai konsekuensi atas bekerjanya sebuah sistem. Tujuan besar penyelenggaraan pemilu untuk menghasilkan pemerintahan yang kredibel dan efektif dalam bekerja, ternyata tidak terlalu berhasil. Partai-partai politik yang diharapkan mampu mengantarkan legislator dan kandidat eksekutif yang mampu tampil untuk mengaktualisasikan dirinya dalam membangun dan menyokong pemerintahan, juga tidak menggembirakan.

Tingkat kepercayaan terhadap partai politik turun. Lembaga eksekutif juga tak mampu menunjukkan diri sebagai lembaga yang merepresentasikan warganegara. Demikian juga legislator yang tidak tampak secara serius memberikan realisasi atas janji-janji politiknya. Itu hanyalah sedikit hal yang dapat dilihat sebagai konsekuensi dari bekerjanya sistem. Legislator cenderung mengabaikan tugasnya sebagai perwakilan konstituen di parlemen. ${ }^{1}$

Perubahan penting telah dilakukan dari hasil pemilu sejaktahun 1999. Diantaranyaperubahan dari daftar tertutup sesuai Undang-Undang Nomor 10 Tahun 2008 tentang Pemilihan Umum Anggota Dewan Perwakilan Rakyat, Dewan Perwakilan Daerah, dan Dewan Perwakilan Rakyat Daerah menjadi daftar terbuka. Dari pelaksanaan pemilu 2009, Mahkamah Konstitusi (MK) mengabulkan tuntutan tentang suara terbanyak dan mengabaikan nomor urut kandidat yang disusun oleh partai. Hal tersebut berdampak pada perubahan strategi kampanye dari kandidat dan sistem dari semi daftar terbuka menjadi daftar terbuka seluruhnya. ${ }^{2}$

Mahkamah Konstitusi memegang posisi penting dalam penyediaan ruang komplain atas produk legislasi. Terkait dengan pemilu, setidaknya terdapat empat jenis putusan yang menarik untuk didalami diantaranya: Penghitungan konversi suara ke alokasi kursi, kemenangan suara terbanyak, ambang batas parlemen dan pemilu legislatif serentak dengan pilpres. Keempat hal tersebut merupakan bagian dari sistem pemilu yang harus diuji konsistensi logika dan asas terhadap implementasinya. Artikel ini bertujuan untuk melakukan tinjauan kritis terhadap konsistensi hasil putusan MK terhadap asas yang diinginkan oleh Undangundang pemilu. Adapun unit analisisnya adalah putusan MK terkait dengan gugatan partai politik untuk alokasi kursi Dewan Perwakilan Rakyat (DPR) yang terkait dengan pemenuhan asas derajat keterwakilan tinggi.

\section{B. Permasalahan}

1. Bagaimana metode penafsiran standar bagi Mahkamah Konstitusi?

2. Sejauhmana klaim dasar tentang keterwakilan tinggi dalam putusan Mahkamah Konstitusi bisa diuji dengan metode ilmiah?

3. Sejauhmana metode penafsiran Mahkamah Konstitusi berdampak pada putusan yang dihasilkannya?

Salah satunya bisa dilihat dalam jajak pendapat yang dilakukan Litbang Kompas, http://nasional.kompas.com/ read/2013/12/23/1156086/Rapor.Merah.Kinerja.Partai.Politik (diakses 27 April 2014).

2 Stephen Sherlock, Indonesia's 2009 Elections: The New Electoral System and the Competing Parties, CDI Policy Papers on Political Governance, Centre for Democratic Institutions, 2009/01. 


\section{Metode Penelitian}

Unit analisis tulisan ini adalah Putusan MK yang berhubungan dengan sengketa pemilu dengan gugatan tentang alokasi kursi yang diajukan oleh partai politik. Tulisan ini disusun dalam beberapa langkah yakni: 1) mengelaborasi tentang metode penafsiran konstitusi. 2) melakukan uji konsistensi putusan MK dengan metode yang spesifik sesuai dengan persoalan yang dibahas dalam unit analisis. 3) memberikan analisis terhadap hasil uji asas tersebut.

\section{Pembahasan}

\section{Uji Konstitusi: Model dan Metode Penafsiran}

Pengujian terhadap konstitusi yang menjadi kewenangan MK menjadi menarik untuk dibahas. Undang-Undang Nomor 8 Tahun 2011 tentang Perubahan Atas Undang-Undang Nomor 24 Tahun 2003 tentang Mahkamah Konstitusi tidak mengatur tentang metode penafsiran standar yang digunakan oleh hakim MK. Hal ini berdampak langsung setidaknya pada dua hal: Pertama, konsistensi putusan MK terbelah antara kecenderungan hukum-dogmatik dan politik-paradigmatik yang terjadi secara silih berganti. Kedua, mempengaruhi sistem politik secara meluas karena setiap putusan MK bersifat final dan berkekuatan hukum tetap dan dapat berdampak pada dianulirnya undang- undang karena dianggap tidak sesuai dengan semangat konstitusi.

Model uji konstitusi secara umum merujuk pada dua tradisi yaitu model Austria yang memberi penekanan pada adanya fungsi lembaga peradilan konstitusi yang terpisah dari lembaga legislatif dan yudikatif. Model Amerika Serikat (AS) yang berpegang pada fungsi uji konstitusi melekat pada kekuasaan yudikatif dibawah Mahkamah Agung. Doktrinnya yang terkenal pernah disampaikan oleh John Marshall tahun 1803, yakni "tugas lembaga peradilan adalah mengatakan apa hukum itu". ${ }^{3}$ Model AS lebih condong pada penggunaan hukum-dogmatik dalam putusan-putusan uji konstitusinya.

Model Austria, sebagaimana yang diadopsi oleh Indonesia, dimulai dengan gagasan Georg Jellinek tentang sebuah lembaga negara yang berfungsi untuk melakukan peninjauan terhadap legislasi yang dibuat oleh parlemen. Gagasan tersebut ditransformasikan dalam bentuknya yang nyata dan diatur dalam konstitusi Austria. Hans Kelsen sebagai penulis draft konstitusi meletakkan gagasannya yang spesifik bahwa negara dan hukum bukanlah fenomena yang terpisah. Disini, mahkamah konstitusi mempunyai fungsi politik untuk melindungi negara dari segenap usaha legal yang mengancam eksistensinya. ${ }^{4}$ Ruang mahkamah berada diantara irisan ruang politik legislasi dengan hukum yudikatif. Mahkamah

3 Principle supposed to be essential to all written constitutions, whereas a law repugnant to the constitution [was] void and that courts were thus capable to review statutes and ordinances with regard to their constitutionality; as it was emphatically the province and duty of the judicial department to say what the law is. William Nelson, Changing Conceptions of Judicial Review, (U Pa L Rev, 1972), hlm. 11-66.

Bisa disimak dalam Mark Tushnet, Marbury v. Madison Around the World, (Tenn L Rev, 2004) hlm. 251. Herbert Haller, Die Prüfung von Gesetzen (1979), hlm. 67. Ludwig Adamovich, Der Verfassungsgerichtshof der Republik Österreich-Geschichte-Gegenwart_Visionen (JRP, 1997), dan juga karya klasik Georg Jellinek, Ein Verfassungsgerichtshof für Österreich (1885) dan Peter Häberle, Verfassungsgerichtsbarkeit XIV (1976). 
menghasilkan negative legis/ation yang berarti dia mempunyai otoritas politik sekaligus diberi wewenang yudikatif untuk menghasilkan putusan hukum.

Penafsiran konstitusi dari tradisi Austria dan Jerman lebih menekankan pada proses komunikasi. Maksud dari komunikasi bukan pada pertukaran opini belaka melainkan tindakan kolektif, keyakinan diri dari komunitas hukum yang mempercayai kepentingan publik terhadap isi konstitusi, Sekalipun interpretasi berkaitan dengan aspek grammatikal, tapi harus menghindari banyaknya metafora dan sejenisnya yang tidak substansial. Pendeknya, menolak permainan kata-kata belaka sebab narasi konteks dimana konstitusi tersebut ditafsirkan sangat terbuka. ${ }^{5}$

Hakim-hakim konstitusi di Austria dan Jerman sangat memperhatikan metode penafsiran konstitusi. Mereka banyak dipengaruhi oleh dinamika pemikiran yang melingkupi, bukan hanya persoalan hukum saja, melainkan pada persoalan politik dan filosofi masyarakat yang berkembang. Penafsiran konstitusi yang bertumpu pada proses komunikasi misalnya, banyak dipengaruhi oleh pemikiran ahli hermeneutik Hans-Georg Gadamer dimana dia menyebutkan bahwa segenap penafsiran selalu melibatkan percakapan antara pembaca dan teks dan berdampak pada hasil yang dimunculkan dari hubungan antara teks dan tujuan serta perspektif pembacanya. ${ }^{6}$ Ahlifilsafat bahasa Ludwig Wittgenstein berpendapat bahwa antara metode dan isi dari interpretasi menunjukkan hubungan antara dua ekspresi linguistik. Baginya persoalan kebenaran logika dari interpretasi dideterminasi oleh konsensus tindakan, bukan opini.?

Karakteristik uji konstitusi terikat dengan bentuk dan model lembaga penguji konstitusi. Dalam model yang diletakkan oleh Hans Kelsen, penafsiran konstitusi harus dilakukan oleh lembaga yang berada diluar wilayah kekuasaan lembaga yudisial biasa. Pandangan Kelsenian cenderung memposisikan Mahkamah Konstitusi sebagai negative legislator. Parlemen mempunyai wewenang sebagai postive legislator yang berarti menciptakan aturan, legislasi sebagai bagian dari kesepakatan politik. Mahkamah mempunyai otoritas untuk membatasi, menganulir dan membatalkan produk legislasi tersebut jika dianggap memunculkan konflik dengan hukum konstitusi. Kelsen melihat bahwa sebuah mahkamah konstitusi yang berdiri secara independen sangat penting untuk mengemban tugas melakukan uji konstitusi atas legislasi yang dibuat parlemen dengan hakim yang dinominasikan secara intuitu personae atau mempunyai spesifikasi khusus. $^{8}$

\footnotetext{
Metode penafsiran yang berkembang di Austria dan Jerman "Verfassungsinterpretation, so die Folgerung, ist deshalb keine Domäne der Wissenschaft, sondern eine Praxis kollektiver Selbstvergewisserung der Rechtsgemeinschaft, in der Überzeugungen über den Inhalt ihrer Verfassung vorgeschlagen, bekämpft, akzeptiert und wieder verworfen werden. Dieses Sprachspiel, dieser Erzählzusammenhang ist offen und hat kein Ende". Ewald Wiederin, Verfassunginterpretation in Osterreich, in Georg Linbacher (Hrsg), Verfassunginterpretation in Europa, (Jan Sramek Verslag, 2011), hlm. 81-155.

6 Hans Georg Gadamer, Wahrheit und Methode. Grundzüge einer philosophischen Hermeneutik. (Tübingen, Unveränd Tübingen, 1975).

Ludwig Wittgenstein, Philosophical Grammar. Juga Ludwig Wittgenstein, On the Foundations of Mathematics (Cambridge, 1939).

8 Hans Kelsen, Reine Rechtslehre, trans Max Knight, Pure Theory of Law (University of California Press, 1989).
} 
Uji konstitusi merupakan bagian dari perlindungan hak-hak warganegara dan segenap lembaga-lembaga yang lain terhadap konstitusi. Kekuasaan lembaga legislatif juga semakin terbatas sekalipun dalam pelaksanaannya, pengujian konstitusi tidak bisa didasarkan pada asumsi politik, melainkan pada logika politik yang sistematik yang memungkinkan munculnya tafsir dari asas yang terkandung didalam konstitusi sebagai sebuah kesepakatan politis. Teks konstitusi ditafsirkan oleh hakim dengan menggunakan metode penafsiran standar. Adapun jenis formula yang umum digunakan yakni teks hukum+Metode penafsiran+Keyakinan hakim+sistematika prosedur hukum = makna hukum. Metode penafsiran menjadi komponen penting yang membuat teks hukum bisa mempunyai arti.

Mahkamah Agung Amerika dan Inggris mengenal beberapa metode umum penafsiran konstitusi yakni: 1) strict originalist yang mendasarkan penafsirannya pada teks literal dari konstitusi dan memberikan perhatian khusus pada siapa saja yang menulis teks tersebut. 2) Evolusionist, yang memberikan perhatian pada aspek perubahan masyarakat. 3) moralist, menggunakan standar moral atau nilai politik tertentu. dan 4) pragmatics, disesuaikan dengan perkembangan zaman kontemporer. ${ }^{9}$ Aturan tertulis tentang penggunaan metode penafsiran konstitusi, diatur didalam Undangundang. Mahkamah Konstitusi Jerman (Bundesverfassunggericht), misalnya, mengatur metode interpretasi mahkamah harus obyektif dan memadai. Beberapa metodenya antara lain:
1) interpretasi grammatikal dari teks konstitusi;

2) Interpretasi sistematik dimana ada koherensi dengan aturan yang lain; 3) Interpretasi historis; 4) Interpretasi genetik; dan 5) interpretasi teleologis.

Standar umum yang berlaku baik dari tradisi Austria-Jerman atau Amerika memuat setidaknya tiga hal. Pertama, interpretasi hakim terhadap teks konstitusi sesuai dengan nilai titik berangkat untuk interpretasi hukum adalah melalui kata-kata didalam konstitusi ( $A$ verbis legis non est recedendum). Kedua, pandangan hakim, pemahaman dan analisisnya mengenai sejarah zaman ditulisnya konstitusi yang mengandung nilai intensi dari semangat yang terkandung dalam sebuah inskripsi instrumen hukum (Animus hominis est anima scripti). Ketiga, pengetahuan hakim terhadap struktur hukum yang berlaku dan koherensinya dengan fungsi sebagai satu keseluruhan sistem yang membawa semangat tak seorangpun mampu memahami dengan baik tanpa melihat keseluruhan (Nemo aliquam partem recte intelligere potest antequam totum perlegit). Segenap kesimpulan atau putusan harus mempunyai sifat logis dengan menjalankan prinsip pembuktian terbalik (argumentum e contrario) dan kesimpulan awal yang meluas atau menyempit (argumentum ad maiore a minus).

\section{Desain dan Cycling Effect Dalam Negasi Legislasi}

Putusan MK dalam sengketa pemilu, terutama yang terkait langsung dengan uji

\footnotetext{
9 Louis E. Wolcher, "A Philosophical Investigation into Methods of Constitutional Interpretation in the United States and The United Kingdom," Virginia Journal of Social Policy \& the Law, Vol. 13:2 (2006).
} 
materiil undang-undang pemilu berdampak langsung pada perubahan sistem pemilu. Putusan yang bernilai menganulir dan menyatakan keseluruhan atau pasal-pasal yang diujikan tidak diberlakukan lagi, memunculkan cycling effect (efek melingkar). Putusan yang menganulir undang-undang mengharuskan putusan baru MK berlaku sebagai aturan dasar sementara. Putusan yang bersifat final dan mengikat tersebut juga mempengaruhi proses legislasi selanjutnya di parlemen.
Pengujian dilakukan untuk menjawab apakah legislasi tersebut bertentangan atau tidak sesuai dengan konstitusi. Proses perdebatan substansi gugatan merupakan ikhtisar hakim MK untuk mendapatkan masukan, perbandingan dan penguatan dari pihakpihak yang mempunyai kompetensi yang jelas dan terukur dibidang yang menjadi substansi gugatan. Jika hal tersebut tidak diperhatikan dengan baik, konsekuensinya bagi kualitas putusan akan berdampak besar bagi perubahan

\section{Bagan 1: Cycling Effect Putusan MK}

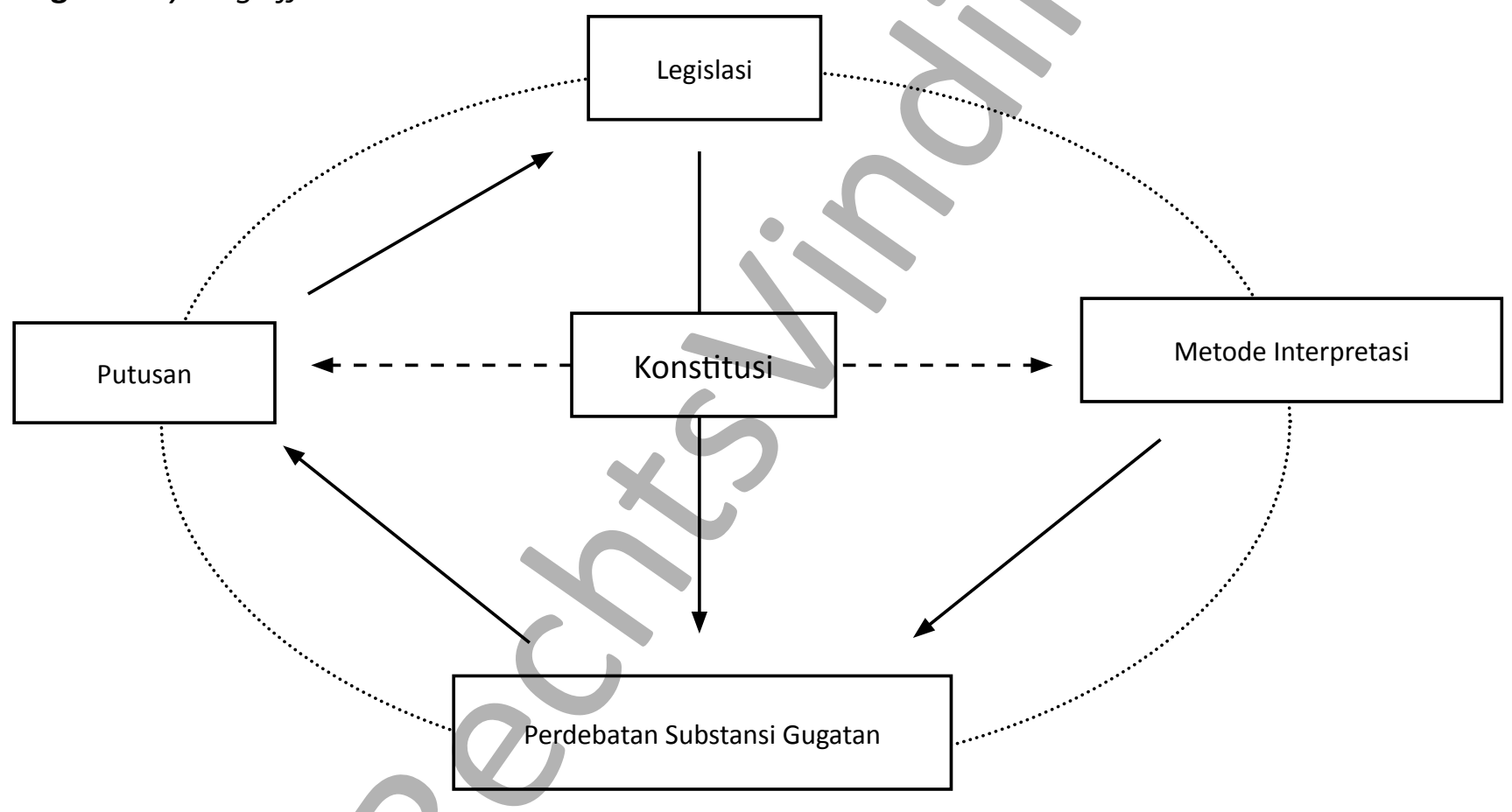

Sumber: Diolah oleh Penulis

Dalam bagan diatas, terdapat hubungan langsung antara konstitusi, metode interpretasi dan hasil putusan. Hubungan tersebut bisa dilihat sebagaisebuah konsistensi antara norma, logika dan sistematika hukum. Proses legislasi mempunyai dimensi politik karena merupakan bagian dari kesepakatan politik yang dihasilkan oleh parlemen. Ketika gugatan terhadap legislasi muncul, maka wilayah yang harus diperhatikan adalah perdebatan substansi gugatannya. legislasi sendiri. Terutama apabila putusan MK justru bertentangan dengan konstitusi yang juga berimbas pada buruknya kualitas legislasi amandemen atau pembaharuan yang dilakukan sebagai tindaklanjut atas putusan MK.

Dari sisi kelembagaan, MK mempunyai beberapa peran dan posisi. Sedikitnya terdapat tiga hal, yaitu: 1) MK mempunyai eksklusivitas atas jurisdiksi konstitusional yang final. Dalam posisi ini, hakim mahkamah melakukan 
monopoli dalam melakukan uji konstitusi; 2) Yurisdiksi mereka terbatas pada perdebatan konstitusi dimana hakim mahkamah tidak melampaui perdebatan yudisial atau litigasi; 3) Mahkamah mempunyai keterhubungan dengan, namun terpisah dari kekuasaan yudisial dan legislatif. Mereka menempati ruang antara politik dan hukum. Ruang ini merupakan irisan sebagaimana disinggung didalam pembahasan sebelumnya. Dibatasi dengan perihal dimana mahkamah terikat dengan sistem norma, hirarki peraturan dan referensi yang kuat. Semuanya didukung oleh kesahihan sumber dan pembuktian. Kesahihan sistematik yang dirunut oleh sistem nalar hakim konstitusi dan tafsirnya menuju pada asas yang dikandung dalam norma dasar.

Mahkamah mempunyai peran sebagai penyeimbang kekuasaan, baik sebagai pelindung hak-hak warganegara maupun konsistensi asas konstitusi yang terjamin keberadaannya. Uji konstitusi atau uji yudisial (judicial review) di banyak negara memunculkan apa yang disebut oleh Ran Hirschl sebagai kendaraan bagi transformasi kekuasaan secara tidak terduga dari lembaga-lembaga representasi politik pada peradilan. ${ }^{10}$ Transformasi tersebut dijamin oleh legitimasi yang dimiliki oleh MK. Ada empat tesis legitimasi spesifik. Tesis pertama, lembaga yudisial tidak mempunyai legitimasi yang inheren. Kedua, legitimasi spesifik dari kekuasaan yudisial dikondisikan oleh aturan hukum yang mempunyai prasyarat adanya struktur dan komposisi dalam kelembagaan, proses yang mengikuti prosedur, isi dan substansi dari keputusan. Ketiga, hukum menyediakan alasan bagi tindakan yudisial dan keputusan yang dibuat harus mempunyai legitimasi. Keempat, hukum mempunyai legitimasi "jika" dan "hanya jika" didukung oleh keputusan politik $^{11}$.

\section{Studi Kasus: Menguji Kadar Keterwakilan dalam Penghitungan Alokasi Kursi}

MK mempunyai kewenangan untuk mengadili sengketa pemilu. Dari uraian tentang metode interpretasi di atas, pembahasan di bawah ini akan melakukan pengujian terhadap kapasitas dan kualitas putusan MK yang terkait dengan alokasi kursi dan kadar keterwakilan dalam distribusinya. Dalam gugatan uji materil yang dilayangkan oleh Partai Hanura dan Partai Gerindra membuat MK memutuskan bahwa Pasal 205 ayat (4) Undang-Undang Nomor 10 Tahun 2008 adalah konstitusional bersyarat. Bunyi inti putusan tersebut adalah "Terkait dengan penghitungan tahap kedua untuk penetapan perolehan kursi DPR dengan cara menentukan kesetaraan 50 persen suara sah dari Bilangan Pembagi Pemilu (BPP) yakni 50 persen dari angka BPP di setiap daerah pemilihan. Lalu membagi sisa kursi pada setiap dapil tersebut kepada partai politik peserta pemilu dengan ketentuan suara sah partai dikategorikan sebagai sisa suara dan diperhitungkan dalam tahapan ketiga". ${ }^{12}$

\footnotetext{
10 Ran Hirschl, Toward Juristocracy: The Origins and Consequences of the New Constitutionalism (Harvard University Press, 2007).

11 Luc B. Tremblay, "General Legitimacy of Judicial Review and the Fundamental basis of Constituional Law," Oxford Journal of Legal Studies, Vol 23 No. 4 (2003): 525-562.

12 "MK Mentahkan Putusan MA", Kompas, 9 Agustus 2009.
} 
Metode perhitungan dengan BPP menjadi dasar bagi segenap putusan MK yang lain berhubungan dengan sengketa alokasi kursi. Tulisan ini akan melakukan tinjauan kritis terhadap Putusan MK Nomor 74-80-94-5967 /PHPU.C-VII/2009 sebagai salah satu putusan yang spesifik membahas tentang alokasi kursi dan keterwakilan tinggi. Dari putusan tentang Bilangan Pembagi Pemilih (BPP). Sebelum memutuskan mengenai sistem alokasi kursi BPP, perlu didalami BPP dalam sistem yang seperti apa?. BPP sejatinya merupakan sistem alokasi kursi berdasarkan kuota. Dalam literatur sistem alokasi kursi, terdapat Kuota Hare, Dropp-Quota atau Hagenbach-Bischoff) atau STV-Dropp-Quota. Masing-masing mempunyai rumus sendiri. Misalnya untuk Kuota Hare, alokasi suara didasarkan pada jumlah total suara sah didalam satu daerah pemilihan dibagi total kursi di dapil yang sama. DroppQuota membagi berdasarkan total suara sah dalam satu dapil dibagi total kursi dapil+1 dan
STV-Dropp-Quota, total suara sah dapil dibagi total kursi dapil+1+1). Sementara BPP dalam pengertian Undang-undang Pemilu Indonesia termasuk dalam kategori Kuota Hare+sisa suara terbanyak. Padahal sisa suara terbanyak atau Largest Reminder (LR) itu bisa didefinisikan lagi besaran sisa terbesar atau terkecil? Sehingga idealnya penghitungan BPP itu menjadi Kuota Hare+LR.

Sistem BPP+Sisa suara terbanyak yang diatur didalam UU Pemilu bisa dirunut sesuai dengan Kuota Hare $=V / S$ dimana $V$ adalah suara sah total di satu dapil dan $S$ adalah total kursi yang tersedia. Sementara Kursi Partai=(Vparpol) $B P P$ (Hare) $+L R$ dimana Vparpol adalah kursi perolehan suara salah satu parpol. Atau juga bisa digabungkan dengan rumus Kursi Parpol= $\left[v_{\text {parpol }} /(V / S)\right]+L R=\left(v_{\text {parpol }} \times S\right) / V+L R$. Mengingat, bukankah Kursi Parpol sama dengan perhitungan $\left(v_{\text {parpol }} / B P P\right)+L R$ ? Dan $B P P_{\text {Hare }}=V / S$ ? . Metode ini disebut juga dengan metode kuota varian Hare/ Hamilton/Niemeyer.

Tabel 1: Perhitungan Pemilu Legislatif Jakarta 2009 Dapil Jakarta I

\begin{tabular}{|c|c|c|c|c|c|c|c|c|}
\hline PARPOL & Suara & Porsi Kursi & Kursi I & $\begin{array}{l}\text { Sisa } \\
\text { Suara }\end{array}$ & $\begin{array}{c}\text { Urutan } \\
\text { Terbanyak }\end{array}$ & $\begin{array}{l}\text { Sisa } \\
\text { Kursi }\end{array}$ & $\begin{array}{l}\text { Kursi } \\
\text { Final }\end{array}$ & $\begin{array}{c}\text { Suara } \\
\text { Hangus }\end{array}$ \\
\hline HANURA & 23.376 & 0,14 & & 0,14 & & & & 23.376 \\
\hline GERINDRA & 57.845 & 0,35 & & 0,35 & & & & 57.845 \\
\hline PKS & 214.541 & 1,29 & 1 & 0,29 & & & 1 & 47689 \\
\hline PAN & 50.870 & 0,30 & & 0,30 & & & & 50.870 \\
\hline PKB & 16.765 & 0,10 & & 0,10 & & & & 16.765 \\
\hline GOLKAR & 73.181 & 0,44 & & 0,44 & (3) & 1 & 1 & \\
\hline PPP & 51.751 & 0,31 & & 0,31 & & & & 51.751 \\
\hline PDI-P & 105.439 & 0,63 & & 0,63 & (1) & 1 & 1 & \\
\hline DEMOKRAT & 407.344 & 2,44 & 2 & 0,44 & $(2)$ & 1 & 3 & \\
\hline JUMLAH SUARA (V) & 1.001 .112 & 6 & & & & & 6 & 248.296 \\
\hline $\operatorname{KURSI}(\mathrm{S})$ & 6 & Sisa Kursi & 3 & & & & & \\
\hline
\end{tabular}

Sumber: Diolah oleh Penulis \& Pipit Kartawidjaja berdasarkan Putusan MK Nomor 74-80-94-59-67/PHPU.C-VII/2009 
Dari tabel I diatas, terlihat metode perhitungan suara dan alokasi kursi dengan metode $\mathrm{BPP}+\mathrm{Sisa}$ suara terbanyak. Metode ini merupakan metode alokasi kursi yang paling proporsional dan bisa meminimalisir hangusnya suara dan bisa menjamin tingkat keterwakilannya menjadi tinggi. ${ }^{13}$ Di titik ini, seolah tidak bermasalah, selain efek dari berlakunya sistem tersebut berpotensi memunculkan banyak paradoks. Persoalan akan muncul jika sistem tersebut diberlakukan bersamaan dengan aturan mengenai ambang batas parlemen. Dalam Putusan MK No. 52/PUU-X/2012, MK memutuskan tidak berlakunya ambang batas parlemen (Parliamentary Treshold/PT) sebesar 3,5 persen berlaku nasional seperti diatur dalam Pasal 8 ayat (1) dan (2) dan Pasal 208 Undang-Undang Nomor 8 Tahun 2012. MK berpendapat besaran PT bertentangan dengan kedaulatan rakyat, hak politik, dan rasionalitas yang bertentangan juga dengan tujuan pemilu untuk memilih wakil rakyat mulai dari tingkat pusat hingga daerah. Sebenarnya, putusan ini tidak mempunyai signifikansi yang jelas bagi penjaminan hak hidup partai-partai kecil. Sebab PT masih tetap diberlakukan.

Dampak dari PT tersebut merugikan partai yang sudah memenuhi BPP didaerah namun karena ditingkat pusat tidak lolos PT, maka dengan sendirinya suara mereka hilang dan partai yang lolos PT bisa menangguk kursi meski BPPnya tidak mencukupi ${ }^{14}$. Terkait dengan metode alokasi kursi, resiko menggunakan kuota Hare/ Niemeyer/Hamilton sangat merugikan partai kecil ketika pada saat yang sama diterapkan ambang batas parlemen (PT). Metode ini rentan munculnya paradoks dimana dalam kondisi perolehan suara parpol B, ketika tanpa ambang batas dapat 2 (dua) kursi, tapi persis dengan ambang batas hanya dapat 1 (satu) kursi, padahal suaranya tetap 701 yang disebabkan pengurangan suara 500 (parpol A). Gejala ini disebut population paradox (karena minus 500) atau new-state paradox (partai berkurang satu) alias threshold-paradox. Hasil perhitungan ini secara matematika pemilu dikatakan tidak konsisten atau tidak "house-monotone". ${ }^{15}$ Cara penghitungan yang benar adalah cara yang konsisten atau house-monotone.

13 Kenneth Benoit, Which Electoral Formula Is the Most Proportional? A New Look with New Evidence, Political Analysis, 8:4, hal. 385, http://polmeth.wustl.edu/analysis/vol/8/PA84-381-388.pdf. dalam tulisannya Benoit membuktikan bahwa metode kuota Hare/hamilton/Niemeyer itu paling bagus diantara yang lain, namun mempunyai kelemahan. Dengan diterapkannya ambang batas, muncul paradoks populasi dan pemekaran wilayah (Population Paradox dan New-State Paradox) yang juga disebut sebagai Threshold Paradox

14 MK: Ambang Batas Parlemen Tak Berlaku Nasional, Kompas, 29 Agustus 2012

15 Prof. Dr. Klaus Kopfermann, "Mathematische Aspekte der Wahlverfahren", (Universitas Hannover, BI Wissenschaftsverlag Mannheim/Wien/Zuerich 1991), hal. 115 atau Michel L. Balinski and H. Peyton Young, „Fair Representation: Meeting the Ideal of One Man, One Vote",( Brooking Institution Press, Washington D.C 2001), hal. $117-118$ 
Tabel 2: Perbandingan Penghitungan Kuota Hare/Hamilton/Niemeyer dengan PT dan non-PT

\begin{tabular}{|c|c|c|c|c|c|c|c|}
\hline \multirow[b]{2}{*}{ Parpol } & \multirow[b]{2}{*}{ Suara } & \multicolumn{2}{|l|}{ TANPA PT } & \multicolumn{4}{|c|}{ DENGAN PT 5\% } \\
\hline & & Porsi Kursi & Kursi & Suara & Porsi Kursi & & Kursi \\
\hline A & 500 & 1,05 & 1 & - & - & & \\
\hline B & 701 & 1,47 & 2 & 701 & & 1,55 & \\
\hline C & 4.399 & 9,24 & 9 & 4.399 & & 9,72 & \\
\hline D & 4.400 & 9,24 & 9 & 4.400 & & 9,73 & \\
\hline JUMLAH & 10.000 & & 21 & 9.500 & & & \\
\hline KURSI & 21 & & & & & & \\
\hline
\end{tabular}

Penghitungan tanpa PT memperlihatkan parpol A sekalipun mendapatkan suara 500, tetap berpeluang mendapatkan 1 buah kursi. Parpol B mendapatkan 2 kursi dan parpol C dan D masing-masing 9 kursi. Sedangkan dengan pemberlakuan PT 5 persen, parpol A tidak
Tabel 3 memperlihatkan, penghitungan tanpa PT memberikan 1 kursi bagi parpol A. Parpol B mendapatkan 2 kursi, parpol $C$ dan D masing-masing 9 kursi. Jika PT 5 persen diterapkan, parpol A kehilangan kursi dan berpindah mejadi kursi tambahan bagi

Tabel 3: Penghitungan Dengan Metode Divisor St Lague/Webster dengan PT dan non-PT

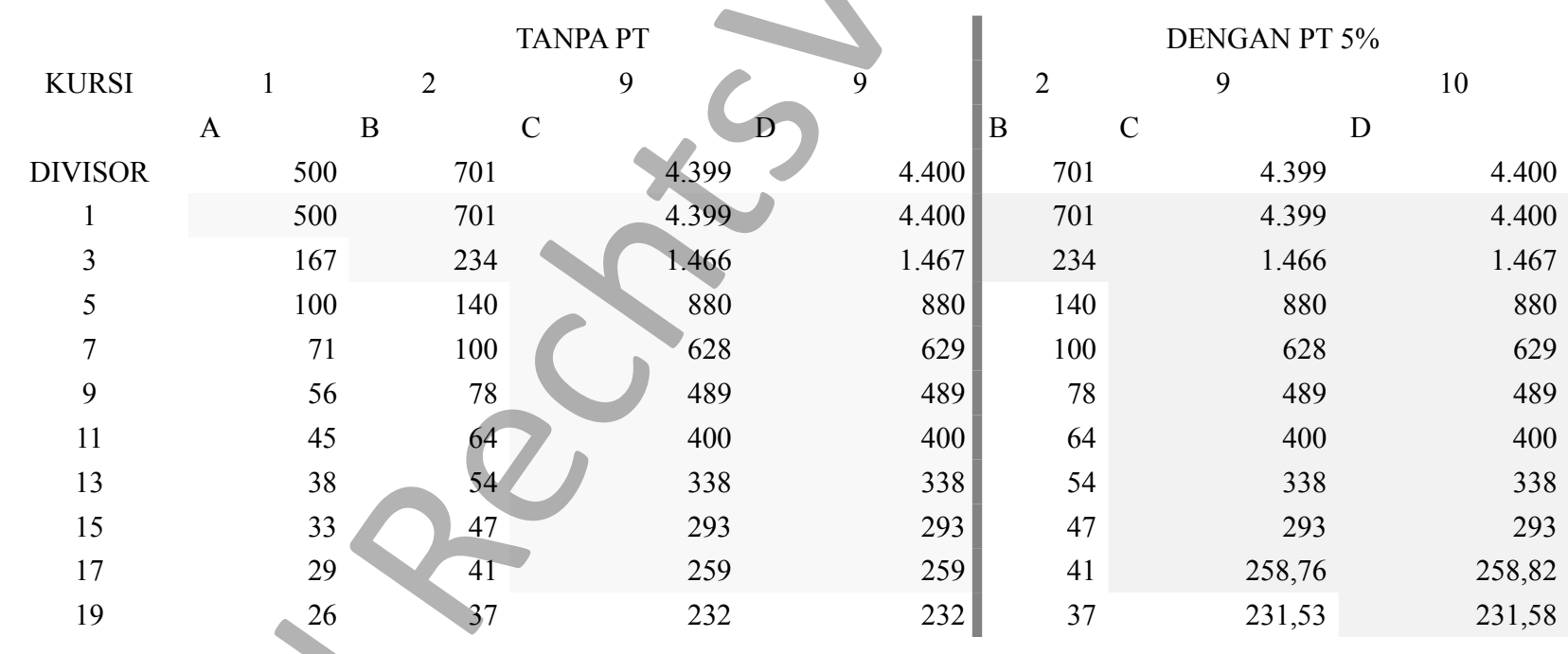

Sumber: olahan Pipit R Kartawidjaja (2014)

mendapatkan kursi, parpol B mendapatkan 1 kursi dan parpol C dan D menangguk keuntungan masing-masing 10 kursi. Penghitungan akan berbeda jika diterapkan metode divisor St Lague/Webster parpol D yang mendapatkan 10 kursi. Metode pengitungan ini lebih meminimalir suara hangus dan lebih menjanjikan stabilitas perolehan kursi bagi parpol secara lebih adil. Mahkamah Konstitusi Jerman pernah menjumpai kasus yang mirip dengan munculnya paradoks dalam penghitungan suara dengan metode Kuota 
Hare/Niemeyer dalam pemilu Bundestag 2009 yang populer disebut negative stimmgewicht akibat population paradox atau new-state population. Dari gugatan pada tahun 2011, maka sejak tahun 2013, pemilu parlemen Jerman (Bundestag) tidak lagi menggunakan kuota Niemeyer melainkan Divisor St. Lague karena dinilai melanggar asas persamaan hak dan peluang parpol untuk meraih kursi. Selain itu, metoda St. Lague/Webster yang tingkat proporsionalitasnya menyetarai metoda kuota Hare/Hamilton/Niemeyer itu, tidak memproduksi paradoks-paradoks seperti dalam metoda kuota Hare/Hamilton/Niemeyer.

Penggunaan metode BPP+Sisa Suara terbanyak dan simulasi diatas menunjukkan perbandingan antara penghitungan secara sektoral (alokasi kursi saja) dengan keterkaitan antara perhitungan alokasi kursi dengan penggunaan ambang batas dalam sebuah sistem pemilu. Menguji satu hal harus memperhatikan, mempertimbangkan dan menghitung juga konsekuensi dari sistem secara umum.

Hasil perhitungan KPU sebagaimana terlihat di tabel I, terdapat hasil penghitungan KPU yang dibatalkan oleh MK. Pembatalan tersebut terkait dengan gugatan yang dilayangkan oleh partai politik dan membuat MK harus melakukan perhitungan ulang alokasi kursi agar sesuai dengan kadar keterwakilan tinggi. Sebelumnya, MA melalui putusannya juga telah melakukan perhitungan, namun tetap dianggap memberatkan penggugat. Dalam perhitungan gugatan di Dapil Jakarta I, tampak perbedaan signifikan antara hasil perhitungan KPU dan MK. MK cenderung mengabaikan prinsip cara penghitungan dengan metode BPP+Sisa Suara Terbanyak atau kuota Hare/Hamilton/ Niemeyer sebagaimana yang dilakukan oleh KPU, bahwa sisa suara dalam metoda kuota Hare/Hamilton/Niemeyer selalu tergantung pada sisa kursi. Jika kursi habis dibagi, maka tak ada lagi sisa suara sementara yang ada adalah suara hangus. Terlebih lagi, cara penghitungan yang dilakukan oleh MK tidak didasari oleh argumentasi dan pendapat ilmiah yang bisa dipertanggungjawabkan. ${ }^{16}$ Secara umum, putusan tersebut memberikan keuntungan dengan menambahkan kursi untuk Gerindra dan PAN. ${ }^{17}$ Jika ditabulasikan, perbandingan alokasi korsi KPU dengan MK untuk DKI Jakarta I bisa dilihat sebagai berikut:

\footnotetext{
16 Putusan MK Nomor 74-80 - 94-59-67 /PHPU.C-VII/2009, hlm. 12. Karena tak satu partai pun meraih BPP Provinsi, maka "penetapan perolehan kursi Partai Politik peserta Pemilu Anggota DPR dilakukan dengan cara membagikan sisa kursi kepada Partai Politik peserta Pemilu Anggota DPR di provinsi satu demi satu berturutturut sampai semua sisa kursi habis terbagi berdasarkan sisa suara terbanyak yang dimiliki oleh tiap Partai Politik secara berurutan."

17 Putusan MK Nomor $74-80$ - 94 - 59 - 67 /PHPU.C-VII/2009, hlm. 13.
} 
Tabel 4: Perbandingan Hasil Penghitungan KPU dan MK untuk DKI Jakarta I

\begin{tabular}{|c|l|r|r|c|}
\hline $\begin{array}{c}\text { No } \\
\text { Partai }\end{array}$ & \multicolumn{1}{|c|}{ Partai Politik } & Suara Sah & $\begin{array}{c}\text { Kursi Final } \\
\text { KPU }\end{array}$ & Kursi Final MK \\
\hline 1 & Partai Hanura & 23.376 & & \\
\hline 5 & Partai Gerindra & 57.845 & & 1 \\
\hline 8 & PKS & 214.541 & 1 & 1 \\
\hline 9 & PAN & 50.870 & & 1 \\
\hline 13 & PKB & 16.765 & & \\
\hline 23 & Partai Golkar & 73.181 & 1 & 1 \\
\hline 24 & PPP & 51.751 & & 2 \\
\hline 28 & PDI-P & 105.439 & 1 & 6 \\
\hline 31 & Partai Demokrat & 407.344 & 3 & 6 \\
\hline & & 1.001 .112 & 6 & 2 \\
\hline
\end{tabular}

Sumber: olahan M Faishal Aminuddin \& Pipit R Kartawidjaja (2014)

Dari perbandingan perhitungan diatas, jika menggunakan standar BPP+Sisa Suara terbanyak, jika sisa kursi habis terbagi seperti dalam Dapil Jakarta II dan III, maka tidak ada lagi sisa suara sebab yang ada hanyalah suara hangus. Di dapil lain yang kursinya habis terbagi dalam tahap pertama dan kedua seperti Banten III, ${ }^{18}$ Dapil Kalsel II, ${ }^{19}$ Dapil NTT II $^{20}$ tidak lagi terdapat sisa suara karena yang ada hanyalah suara hangus, yang tidak disertakan dalam hitungan.

Selain hasil perhitungan yang tidak jelas, MK tidak mempertimbangkan aspek yang lain bahwa UU Pileg 2008 itu mengamanatkan misi pemilu legislatif adalah "menjamin prinsip keterwakilan" dan "mempunyai derajat keterwakilan yang lebih tinggi". ${ }^{21}$ Oleh sebab itu, ditetapkan "sistem proporsional terbuka".22 Disebut proporsional karena bila porsi perolehan suara setiap parpol atau porsi penduduk setiap daerah pemilihan dalam satu pemilu $\left(v_{i} / V\right)$ sama dengan porsi perolehan kursi parlemen setiap parpol atau porsi perolehan kursi parlemen setiap daerah pemilihan $\left(s_{i} / S\right) .{ }^{23}$ Cara yang dilakukan untu mengukur proporsionalitas bisa menggunakan metode yang diambil oleh The

\footnotetext{
Putusan MK Nomor 74 - 80 - 94 - 59 - 67 /PHPU.C-VII/2009, hlm. 17-18.

Putusan MK Nomor 74 - 80 - 94 - 59 - 67 /PHPU.C-VII/2009, hlm. 21-23.

Putusan MK Nomor 74 - 80 - 94 - 59 - 67 /PHPU.C-VII/2009, hlm. 23-29.

BAB I Umum dalam Penjelasan atas Undang-Undang Nomor 10 Tahun 2008.

Pasal 5 ayat (1) Undang-Undang Nomor 10 Tahun 2008.

Douglas W. Rae, The Political Consequens of Electoral Laws, New Haven and London, (Yale University Press 1967), hlm. 18; Philip Kestelman, "Apportionment and Proportionality: A Measured View" dalam Voting Matters, Issue 20, hlm. 12 .
} 
Independent Commission on the Voting System Inggris secara resmi menggunakan Indeks Disproporsionalitas Loosemore-Hanby Index (LHI):

$$
\text { LHI }(\text { percent })=\frac{1}{2} \sum\left|V_{P} \%-S_{P} \%\right|
$$

dengan $V_{p}=$ persentase suara

$$
S_{P}=\text { persentase kursi }
$$

atau sama dengan

LHI $=1 / 2\left[\sum\left[\left(v_{i} / V-s_{i} / S\right)\right]\right.$

dengan $V_{i}=$ perolehan suara parpol $i$ di satu dapil

$V=$ total perolehan suara segenap parpol di satu dapil

$S_{i}=$ perolehan kursi parpol $i$ di satu dapil

$S=$ total kursi di satu dapil

Atau menggunakan rumusan yang standar digunakan didunia akademik yakni Indeks Disporporsionalitas Gallagher (GhI ${ }^{24}$

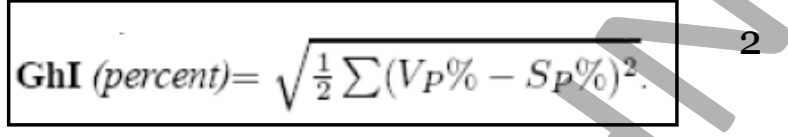

atau sama dengan Least Squares Index (LSq)

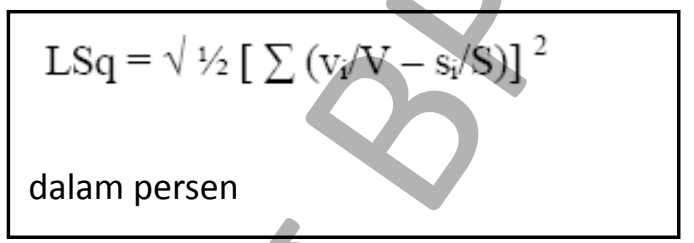

Kedua indeks diatas menyebutkan bahwa semakin kecil perhitungan ke angka ke $0 \%$, berarti semakin proporsional. Jika kita lihat putusan MK tentang aspek proporsionalitas ini, bisa dilihat dalam tabel 5 dan 6 dimana hasil penghitungan yang dilakukan oleh MK bernilai sangat buruk.

\begin{tabular}{|c|c|c|c|c|c|c|c|}
\hline \multicolumn{4}{|c|}{ Dapil DKI Jakarta I - Alokasi Kursi versi KPU } & $\mathrm{v}_{\mathrm{i}} / \mathrm{V}$ atau & $\mathrm{s}_{\mathrm{i}} / \mathrm{S}$ atau & \multirow[b]{2}{*}{ |\%V - \%S| } & \multirow[b]{2}{*}{$\left(v_{i} / V-s_{i} / S\right)^{2}$} \\
\hline PARPOL & $\begin{array}{c}\text { Perolehan } \\
\text { Suara }\end{array}$ & Kursi & 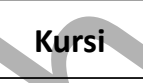 & \% Suara (V) & \% Kursi (S) & & \\
\hline HANURA & 23.376 & $14,01 \%$ & & $2,34 \%$ & $0,00 \%$ & $2,34 \%$ & $0,05 \%$ \\
\hline GERINDRA & 57.845 & $34,67 \%$ & I & $5,78 \%$ & $0,00 \%$ & $5,78 \%$ & $0,33 \%$ \\
\hline PKS & 214.541 & $128,58 \%$ & 1 & $21,43 \%$ & $16,67 \%$ & $4,76 \%$ & $0,23 \%$ \\
\hline PAN & 50.870 & $30,49 \%$ & ) & $5,08 \%$ & $0,00 \%$ & $5,08 \%$ & $0,26 \%$ \\
\hline PKB & 16.765 & $10,05 \%$ & & $1,67 \%$ & $0,00 \%$ & $1,67 \%$ & $0,03 \%$ \\
\hline GOLKAR & 73.181 & $43,86 \%$ & 1 & $7,31 \%$ & $16,67 \%$ & $9,36 \%$ & $0,88 \%$ \\
\hline PPP & 51.751 & $31,02 \%$ & & $5,17 \%$ & $0,00 \%$ & $5,17 \%$ & $0,27 \%$ \\
\hline PDI-P & 105.439 & $63,19 \%$ & 1 & $10,53 \%$ & $16,67 \%$ & $6,14 \%$ & $0,38 \%$ \\
\hline DEMOKRAT & 407.344 & $244,13 \%$ & 3 & $40,69 \%$ & $50,00 \%$ & $9,31 \%$ & $0,87 \%$ \\
\hline JUMLAH & 1.001 .112 & & 6 & & & $49,61 \%$ & $3,29 \%$ \\
\hline \multirow[t]{2}{*}{ KURSI } & 6 & & & & LHI & $24,81 \%$ & \\
\hline & 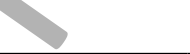 & & & & & Ghl & $12,82 \%$ \\
\hline
\end{tabular}

Tabel 5: Indeks Disporporsionalitas hitungan KPU

Sumber: olahan Pipit R Kartawidjaja (2014)

24 Arend Lijphart, Electoral Systems And Party Systems (Oxford University Press: New York, 1994), hlm. 58-67. Kenneth Benoit, "District Magnitude, Electoral Formula, and the number of Parties", European Journal of Political Research, (2001): 208-209. 
Tabel 6: Indeks Disporporsionalitas hitungan MK

\begin{tabular}{|c|c|c|c|c|c|c|c|}
\hline \multicolumn{4}{|c|}{ Dapil DKI Jakarta I - Alokasi Kursi versi MK } & \multirow{2}{*}{$\frac{\mathrm{v}_{\mathrm{i}} / \mathrm{V} \text { atau }}{\% \text { Suara }(\mathrm{V})}$} & \multirow{2}{*}{$\frac{\mathrm{s}_{\mathrm{i}} / \mathrm{S} \text { atau }}{\text { \% Kursi (S) }}$} & \multirow[b]{2}{*}{$|\% \mathrm{~V}-\% \mathrm{~S}|$} & \multirow[b]{2}{*}{$v_{i}\left(V-s_{i} / S\right)^{2}$} \\
\hline PARPOL & $\begin{array}{l}\text { Perolehan } \\
\text { Suara }\end{array}$ & Kursi & Kursi & & & & \\
\hline HANURA & 23.376 & $14,01 \%$ & & $2,34 \%$ & $0,00 \%$ & $2,34 \%$ & $0,05 \%$ \\
\hline GERINDRA & 57.845 & $34,67 \%$ & 1 & $5,78 \%$ & $16,67 \%$ & $10,89 \%$ & $1,19 \%$ \\
\hline PKS & 214.541 & $128,58 \%$ & 1 & $21,43 \%$ & $16,67 \%$ & $4,76 \%$ & $0,23 \%$ \\
\hline PAN & 50.870 & $30,49 \%$ & 1 & $5,08 \%$ & $16,67 \%$ & $11,59 \%$ & $1,34 \%$ \\
\hline PKB & 16.765 & $10,05 \%$ & & $1,67 \%$ & $0,00 \%$ & $1,67 \%$ & $0,03 \%$ \\
\hline GOLKAR & 73.181 & $43,86 \%$ & & $7,31 \%$ & $0,00 \%$ & $7,31 \%$ & $0,53 \%$ \\
\hline PPP & 51.751 & $31,02 \%$ & & $5,17 \%$ & $0,00 \%$ & $5,17 \%$ & $0,27 \%$ \\
\hline PDI-P & 105.439 & $63,19 \%$ & 1 & $10,53 \%$ & $16,67 \%$ & $6,14 \%$ & $0,38 \%$ \\
\hline DEMOKRAT & 407.344 & $244,13 \%$ & 2 & $40,69 \%$ & $33,33 \%$ & $7,36 \%$ & $0,54 \%$ \\
\hline JUMLAH & 1.001 .112 & & 6 & & & $57,23 \%$ & $4,56 \%$ \\
\hline KURSI & 6 & & & & & $28,62 \%$ & \\
\hline & & & & & & Ghl & $15,09 \%$ \\
\hline
\end{tabular}

Sumber: Olahan Pipit R Kartawidjaja (2014)

Perhitungan KPU mencatatkan Ghl 12,82 persen dan LHI sebesar 24,81 persen. Sedangkan MK mencatatkan Ghl sebesar 15,09 persen dan LHI sebesar 28,62 persen. Jika dianalisis melalui kedua formula diatas, hasil perhitungan yang dilakukan oleh KPU juga lebih proporsional daripada MK. Dari sini sudah terlihat bahwa perhitungan KPU sudah merepresentasikan derajat keterwakilan lebih tinggi daripada perhitungan MK. Namun oleh MK, hasil perhitungan tersebut dibatalkan. Selain dilihat dari derajat LHI dan Ghl, keterwakilan politik juga bisa dihitung berdasarkan formula yang lebih spesifik dimana yang dilihat adalah interval deviasinya. Perhitungan tentang besaran derajat keterwakilan dikemukakan oleh Friedrich Pukelsheim ${ }^{26}$ yang dirumuskan sebagai berikut:

\section{Andil ideal Per Pemilih:}

$$
s_{i} / v_{i}=S / V
$$

\footnotetext{
$s_{i}$ : perolehan kursi parpol i di satu dapil

$v_{i}$ : perolehan suara parpol i di satu dapil

S: total kursi di satu dapil

V: total suara di satu dapil
}

Artinya, andil kursi seorang pemilih parpol i idealnya harus sama dengan andil kursi seorang pemilih di daerah pemilihan tersebut atau dapat diformulasikan:

\section{Derajat Keterwakilan Per Pemilih: $\left(s_{i} / v_{i}\right) /(S / V)=1$}

\section{1: Andil ideal}


Karena pada kenyataannya andil kursi seorang pemilih parpol i tidak sama dengan andil kursi seorang pemilih di daerah pemilihan tersebut, maka dicari selisih atau deviasi andil kursi seorang pemilih parpol i dari andil kursi seorang pemilih di daerah pemilihan tersebut, sehingga formulanya menjadi:

Selisih Derajat Keterwakilan Per Pemilih:

$\left(s_{i} / v_{i}\right) /(s / v)-1$
Dari formula Pukelsheim diatas, bisa kita lihat di tabel 7 dan 8 hasil perhitungan yang dilakukan oleh MK terhadap sengketa alokasi di Dapil Jakarta I. Deviasi (Selisih) Alokasi Kursi seorang pemilih dari keseluruhan parpol hitungan KPU tercatat 7,3136. Sementara MK mencatat deviasi alokasi kursi seorang pemilih dari keseluruhan parpol hitungan MK tercatat 9,1500. Dari perhitungan tentang deviasi ini bisa diketahui bahwa perhitungan KPU lebih baik karena mempunyai tingkat deviasi lebih rendah daripada perhitungan $M \mathrm{MK}^{26}$

Tabel 7: Deviasi Perhitungan KPU dengan Dalil Pukelsheim

\begin{tabular}{|c|c|c|c|c|c|c|c|}
\hline \multicolumn{8}{|c|}{ Dapil DKI Jakarta I - Alokasi Kursi versi KPU } \\
\hline PARPOL & $\begin{array}{c}\text { Perolehan } \\
\text { Suara }\end{array}$ & Kursi & $s_{i} / v_{i}$ & S/V & $\begin{array}{c}\text { Derajat } \\
\text { Keterwakilan: } \\
\left(\mathbf{s}_{\mathrm{i}} / \mathbf{v}_{\mathrm{i}}\right) /(\mathrm{S} / \mathrm{V})\end{array}$ & $\left\{\left(s_{i} / v_{i}\right) /(S / V)\right\}-1$ & $\begin{array}{l}\text { Deviasi Mutlak: } \\
\begin{array}{c}\mid\left\{\left(s_{i} / v_{i}\right) /(S / V)\right\} \\
-1 \mid\end{array}\end{array}$ \\
\hline HANURA & 23.376 & & 0,000000 & 0,000006 & 0,0000 & $-1,0000$ & 1,0000 \\
\hline GERINDRA & 57.845 & & 0,000000 & 0,000006 & 0,0000 & $-1,0000$ & 1,0000 \\
\hline PKS & 214.541 & 1 & 0,000005 & 0,000006 & 0,7777 & $-0,2223$ & 0,2223 \\
\hline PAN & 50.870 & & 0,000000 & 0,000006 & 0,0000 & $-1,0000$ & 1,0000 \\
\hline PKB & 16.765 & & 0,000000 & 0,000006 & 0,0000 & $-1,0000$ & 1,0000 \\
\hline GOLKAR & 73.181 & & 0,000014 & 0,000006 & 2,2800 & 1,2800 & 1,2800 \\
\hline PPP & & & 0,000000 & 0,000006 & 0,0000 & $-1,0000$ & 1,0000 \\
\hline PDI-P & 105 & 1 & 0,000009 & 0,000006 & 1,5825 & 0,5825 & 0,5825 \\
\hline DEMOKRAT & 7.344 & 3 & 0,0000074 & 0,000006 & 1,2288 & 0,2288 & 0,2288 \\
\hline JUMLAH & 12 & 6 & & & & Total Deviasi & 7,3136 \\
\hline KURSI & 8 & & & & & & \\
\hline BPP & & & & & & & \\
\hline
\end{tabular}

Sumber: olahan M Faishal Aminuddin \& Pipit R Kartawidjaja (2014)

26 Data diolah dari Putusan MK Nomor 74 - 80 - 94 - 59 - 67 /PHPU.C-VII/2009, hlm. 11-15. 
Tabel 8: Deviasi perhitungan MK dengan Dalil Pukelsheim ${ }^{27}$

\begin{tabular}{|c|c|c|c|c|c|c|c|}
\hline \multicolumn{8}{|c|}{ Dapil DKI Jakarta I - Alokasi Kursi versi MK } \\
\hline PARPOL & $\begin{array}{c}\text { Perolehan } \\
\text { Suara }\end{array}$ & Kursi & $s_{i} / v_{i}$ & $s / v$ & $\begin{array}{c}\text { Derajat Keter- } \\
\text { wakilan: } \\
\left(s_{i} / v_{i}\right) /(S / V)\end{array}$ & $\left\{\left(s_{i} / v_{i}\right) /(S / V)\right\}-1$ & $\begin{array}{c}\text { Deviasi Mutlak: } \\
\left\{\left\{\left(s_{i} / v_{i}\right) /(S / V)\right\}-1 \mid\right.\end{array}$ \\
\hline HANURA & 23.376 & & 0,000000 & 0,000006 & 0,0000 & $-1,0000$ & 1,0000 \\
\hline GERINDRA & 57.845 & 1 & 0,000017 & 0,000006 & 2,8845 & 1,8845 & 1,8845 \\
\hline PKS & 214.541 & 1 & 0,000005 & 0,000006 & 0,7777 & $-0,2223$ & 0,2223 \\
\hline PAN & 50.870 & 1 & 0,000020 & 0,000006 & 3,2800 & 2,2800 & 2,2800 \\
\hline PKB & 16.765 & & 0,000000 & 0,000006 & 0,0000 & $-1,0000$ & 1,0000 \\
\hline GOLKAR & 73.181 & & 0,000000 & 0,000006 & 0,0000 & $-1,0000$ & 1,0000 \\
\hline PPP & 51.751 & & 0,000000 & 0,000006 & 0,0000 & $-1,0000$ & 1,0000 \\
\hline PDI-P & 105.439 & 1 & 0,000009 & 0,000006 & 1,5825 & 0,5825 & 0,5825 \\
\hline DEMOKRAT & 407.344 & 2 & 0,000005 & 0,000006 & 0,8192 & $-0,1808$ & 0,1808 \\
\hline JUMLAH & 1.001 .112 & 6 & & & & Total Deviasi & 9,1500 \\
\hline KURSI & 6 & & & & & & \\
\hline BPP & 166.852 & & & & & & \\
\hline
\end{tabular}

Sumber: olahan M Faishal Aminuddin \& Pipit R Kartawidjaja (2014)

Dalil Pukelsheim yang memberikan penekanan atas perhitungan deviasi dapat membuktikan seberapa melenceng hasil perhitungan yang dilakukan terhadap distribusi atau alokasi kursi dari perolehan suara partai politik. Dari uraian diatas, dapat dipahami bahwa putusan MK yang membatalkan hasil perhitungan suara KPU yang sudah dilakukan sesuai dengan UndangUndang Nomor 10 Tahun 2008 membuktikan perlunya pengujian atas konsistensi asas yang sudah diatur dan dijelaskan didalam undangundang. UUD 1945 amandemen tidak mengatur dengan spesifik mengenai kadar keterwakilan dan penjelasan yang lebih detail diserahkan kepada undang-undang.

\section{E. Penutup}

\section{Kesimpulan}

Tulisan ini memberikan simpulan bahwa metode interpretasi mempunyai peranan yang penting dalam menghasilkan putusan yang berkualitas. Terdapat dua tradisi metode interpretasi atas uji konstitusi yakni tradisi Amerika-Inggris dan Tradisi Austria-Jerman dimana masing-masing mempunyai penekanan dan spesifikasi yang berbeda sesuai dengan nalar, struktur dan model keorganisasian lembaganya. Putusan MK mempunyai pengaruh yang besar bagi proses legislasi. Efek melingkar dari putusan tersebut berdampak pada dibatakannya sebuah legislasi karena dianggap melanggar konstitusi. Dalam kasus rendahnya kualitas putusan, juga 
berdampak pada kualitas legislasi yang dibuat sebagai perbaikan setelah keluarnya putusan MK.

Hasil uji ilmiah untuk mengukur derajat keterwakilan tinggi dalam alokasi kursi dengan menggunakan Indeks Gallagher dan Derajat Deviasi Pukelsheim dengan membandingkan putusan KPU dan MK memperlihatkan kualitas dari putusan MK tidak lebih baik daripada putusan KPU yang dibatalkannya. Faktor utama dari munculnya hal tersebut adalah minimnya usaha dari hakim konstitusi untuk memperkaya perdebatan substansi gugatan. Kendala pada teknik metode interpretasi yang kurang jelas ruang dan lingkupnya dan kemauan untuk mendatangkan pihak yang mampu memberikan penjelasan ilmiah untuk mengatasi terbatasnya pengetahuan hakim konstitusi terhadap persoalan-persoalan diluar bidang hukum.

\section{Saran}

Dari pembahasan didalam artikel ini, terdapat dua saran yang perlu dipertimbangkan yaitu: Metode interpretasi konstitusi perlu diatur didalam Undang-undang tentang Mahkamah Konstitusi dengan lebih spesifik. Perdebatan substansi gugatan perlu diperluas jangkauannya, bukan hanya mendengar opini penggugat dan tergugat saja melainkan juga melakukan perbandingan ditempat atau negara lain sebagai referensi tentang konsekuensi dari sebuah persoalan yang digugat.

\section{DAFTAR PUSTAKA}

\section{Buku}

Balinski, Michel L. and H. Peyton Young, Fair Representation: Meeting the Ideal of One Man, One Vote (Washington D.C: Brooking Institution Press, 2001).
Gadamer, Hans Georg, Wahrheit und Methode. Grundzüge einer philosophischen Hermeneutik (Aufl. Tübingen, 1975).

Häberle, Peter, Verfassungsgerichtsbarkeit (Darmstadt, XIV, 1976).

Haller, Herbert, Die Prüfung von Gesetzen: ein Beitrag zur verfassungsgerichtlichen Normenkontrolle (Wien, Springer, 1979).

Hirschl, Ran, Toward Juristocracy: The Origins and Consequences of the New Constitutionalism, (Harvard University Press, 2007).

Jellinek, Georg, Ein Verfassungsgerichtshof für Österreich (Alfred Holder Buchhandler, Wien, 1885).

Kartawidjaja, Pipit R \& M. Faishal Aminuddin, Demokrasi Elektoral: Perbandingan, Sistem dan Metode Kepartaian dan Pemilu (Surabaya: Sindikasi Press, 2014).

Kelsen, Hans, Reine Rechtslehre, (trans) Max Knight, Pure Theory of Law (University of California Press, 1989)

Kopfermann, Klaus, Mathematische Aspekte der Wahlverfahren (BI Wissenschaftsverlag Mannheim/Wien/Zuerich: Universitas Hannover, 1991).

Lijphart, Arend, Electoral Systems and Party Systems (New York: Oxford University Press, 1994).

Linbacher, Georg (Hrsg), Verfassunginterpretation in Europa (Jan Sramek Verslag, 2011).

Rae, Douglas W., The Political Consequens of Electoral Laws, (New Haven and London: Yale University Press, 1967).

Wiederin, Ewald, Verfassunginterpretation in Osterreich, in Georg Linbacher (Hrsg), Verfassunginterpretation in Europa (Jan Sramek Verslag, 2011).

Wittgenstein, Ludwig, On the Foundations of Mathematics (Cambridge University Press, 1939).

\section{Makalah / Artikel / Prosiding / Hasil Penelitian}

Benoit, Kenneth, "Which electoral formula is the most proportional?: a new look with new evidence", Political Analysis, 8:4 (2000).

Benoit, Kenneth, "District magnitude, electoral formula, and the number of parties European", Journal of Political Research, 39:2 (2001).

Friedrich Pukelsheim, "Mandatszuteilungen bei Verhältniswahlen: Idealansprüche der Parteien", Zeitschrift für Politik, 47 (2000). 
Friedrich Pukelsheim, "Mandatzuteilungen bei Verhaeltniswahlen: Vetretungsgewichte der Mandate", Kritische Vierteljahresschrift fuer Gesetzgebung und Rechtswissenschaft 83 (2000).

Louis E. Wolcher, "A Philosophical Investigation into Methods of Constitutional Interpretation in the United States and The United Kingdom", Virginia Journal of Social Policy \& the Law, Vol. 13:2, (2006).

Luc B. Tremblay, "General Legitimacy of Judicial Review and the Fundamental basis of Constituional Law", Oxford Journal of Legal Studies, Vol 23 no 4 (2003).

Ludwig Adamovich, "Der Verfassungsgerichtshof der Republik Österreich-GeschichteGegenwart-Visionen", (JRP 1997).

Mark Tushnet, "Marbury v. Madison Around the World", Tennesse Law Review (2004).

Philip Kestelman, "Apportionment and Proportionality: A Measured View" dalam Voting Matters, Issue 20.

Stephen Sherlock, "Indonesia's 2009 Elections: The New Electoral System and the Competing Parties", CDI Policy Papers on Political Governance, Centre for Democratic Institutions (2009/01)
William Nelson, "Changing Conceptions of Judicial Review", University of Pennsylvania Law Review (1972).

Kompas, 29 Agustus 2012: MK: Ambang Batas Parlemen Tak Berlaku Nasional.

Kompas, 9 Agustus 2009: MK Mentahkan Putusan MA.

\section{Internet}

http://nasional.kompas.com/read/2013/12/23/ 1156086/Rapor.Merah.Kinerja.Partai.Politik. (diakses 27 April 2014).

\section{Peraturan}

Undang-Undang Nomor 10 Tahun 2008 tentang Pemilihan Umum Anggota Dewan Perwakilan Rakyat, Dewan Perwakilan Daerah, dan Dewan Perwakilan Rakyat Daerah

\section{Putusan Pengadilan}

MKRI Putusan Nomor $74-80-94-59-67$ / PHPU.C-VII/2009. 